\title{
Drivers of nitrogen leaching from organic layers in Central European beech forests
}

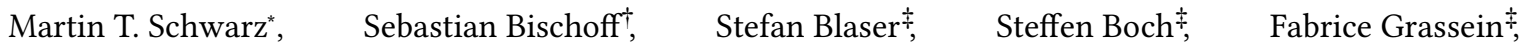 \\ Bernhard Klarner $\$$ Barbara Schmitt $\ddagger^{\ddagger} \quad$ Emily F. Solly $\mathbb{\mathbb { I }}$ Christian Ammer", Beate Michalzik ${ }^{\dagger}$, \\ Peter Schall", Stefan Scheu ${ }^{\S}, \quad$ Ingo Schöning", $\quad$ Marion Schrumpf*, $\quad$ Ernst-Detlef Schulze*, \\ Jan Siemens ${ }^{\dagger \dagger} \quad$ Wolfgang Wilcke ${ }^{\ddagger \dagger}$
}

This is an author's self-archiving version under permission of Springer International Publishing Switzerland 2016. The final publication is available at Springer via http://dx.doi.org/10.1007/s11104-016-2798-0. Please cite the original article:

Schwarz MT, Bischoff S, Blaser S, Boch S, Grassein F, Klarner B, Schmitt B, Solly EF, Ammer C, Michalzik B, Schall P, Scheu S, Schöning I, Schrumpf M, Schulze ED, Siemens J \& Wilcke W (2016) Drivers of nitrogen leaching from organic layers in Central European beech forests. Plant Soil. doi:10.1007/s11104-016-27980 .

\section{Keywords}

- terrestrial nitrogen cycling • ecosystem functioning • litter leachate $\bullet$ organic layer $\bullet$ Biodiversity Exploratories $\bullet$ deciduous forest

\footnotetext{
"Corresponding author: M.T.Schwarz@outlook.com; University of Berne, Institute of Geography, Hallerstrasse 12, 3012 Berne, Switzerland; Present address: wasser/schnee/lawinen, Ingenieurbüro André Burkard AG, Sebastiansplatz 1, 3900 Brig-Glis, Switzerland

${ }^{\dagger}$ Friedrich Schiller University of Jena, Institute of Geography, Löbdergraben 32, 07743 Jena, Germany

¥University of Berne, Institute of Plant Sciences and Botanical Garden, Altenbergrain 21, 3013 Berne, Switzerland

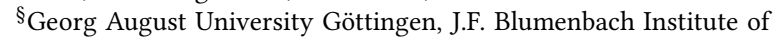
Zoology and Anthropology, Berliner Str. 28, 37073 Göttingen, Germany

ISwiss Federal Research Institute WSL, Forest Soils and Biogeochemistry, Zürcherstrasse 111, 8903 Birmensdorf, Switzerland

"Georg August University Göttingen, Faculty of Forest Sciences, Silviculture and Forest Ecology of the Temperate Zones, Büsgenweg 1, 37077 Göttingen, Germany

${ }^{* *}$ Max Planck Institute for Biogeochemistry, Hans-Knöll-Strasse 10, 07745 Jena, Germany

$\dagger \dagger$ Justus-Liebig-University of Giessen, Institute of Soil Science and Soil Conservation, Heinrich-Buff-Ring 26-32, 35392 Giessen, Germany

¥†Karlsruhe Institute of Technology (KIT), Institute of Geography and Geoecology, Reinhard-Baumeister-Platz 1, 76131 Karlsruhe, Germany
}

\begin{abstract}
Background and Aims: The response of forest ecosystems to continuous nitrogen $(\mathrm{N})$ deposition is still uncertain. We investigated imports and exports of dissolved $\mathrm{N}$ from mull-type organic layers to identify the controls of $\mathrm{N}$ leaching in Central European beech forests under continuous $\mathrm{N}$ deposition.
\end{abstract}

Methods: Dissolved $\mathrm{N}$ fluxes with throughfall and through mull-type organic layers (litter leachate) were measured continuously in 12 beech forests on calcareous soil in two regions in Germany over three consecutive growing seasons.

Results: Mean growing season net (i.e. litter leachate - throughfall flux) fluxes of total dissolved N (TDN) from the organic layer were low $\left(2.3 \pm 5.6 \mathrm{~kg} \mathrm{ha}^{-1}\right)$ but varied widely from $12.9 \mathrm{~kg} \mathrm{ha}^{-1}$ to $-8.3 \mathrm{~kg} \mathrm{ha}^{-1}$. The small increase of dissolved $\mathrm{N}$ fluxes during the water passage through mull-type organic layers suggested that high turnover rates coincided with high microbial $\mathrm{N}$ assimilation and plant $\mathrm{N}$ uptake. Stand basal area had a positive feedback on $\mathrm{N}$ fluxes by providing litter for soil organic matter formation. Plant diversity, especially herb diversity, reduced dissolved $\mathrm{N}$ fluxes. Soil fauna biomass increased $\mathrm{NO}_{3}{ }^{-} \mathrm{N}$ fluxes with litter leachate by stimulating mineralization. Microbial biomass measures were not related to dissolved $\mathrm{N}$ fluxes.

Conclusions: Our results show that dissolved N exports from organic layers contain significant amounts of throughfall-derived $\mathrm{N}$ (mainly $\mathrm{NO}_{3}{ }^{-}-\mathrm{N}$ ) that flushes through the organic layer but also highlight that $\mathrm{N}$ leaching from organic layers is driven by the complex interplay of plants, animals and microbes. Furthermore, diverse understories reduce $\mathrm{N}$ leaching from Central European beech forests. 


\section{Introduction}

While the internal recycling of nitrogen $(\mathrm{N})$ in forest ecosystems through decomposition and mineralization of organic matter primarily controls plant available N (Park et al. 2002), continuously elevated atmospheric deposition of reactive $\mathrm{N}$ has become an important additional component of $\mathrm{N}$ cycling in temperate forests (De Vries et al. 2006; Tørseth et al. 2012). Excessive atmospheric $\mathrm{N}$ deposition is regarded as a major threat for ecosystem functioning, stability and services like fresh-water supply (Millennium Ecosystem Assessment 2005). Organic layers play a key role for $\mathrm{N}$ retention of forests (Nadelhoffer et al. 1995). The latter authors found that organic layers in temperate hardwood forests contribute 40 to $80 \%$ to total ecosystem $\mathrm{N}$ retention. The response of the $\mathrm{N}$ budget of European forest ecosystems to $\mathrm{N}$ deposition, however, is varied. Increased $\mathrm{NO}_{3}{ }^{-}$leaching was observed mainly in coniferous forests with a low $\mathrm{C}: \mathrm{N}$ ratio in the organic layer (MacDonald et al. 2002; Prietzel and Bachmann 2012). Durka et al. (1994) showed that $80 \%$ of $\mathrm{NO}_{3}{ }^{-}$from atmospheric deposition bypasses the ecosystem $\mathrm{N}$ cycle and enters into groundwater in a Norway spruce (Picea abies (L.) H. Karst) forest. For a range of Central European beech (Fagus sylvatica $\mathrm{L}$.) forests, $\mathrm{N}$ accumulation in the soil ranged -24 to $+11 \mathrm{~kg} \mathrm{ha}^{-1}$ year $^{-1}$ (Brumme and Khanna 2008).

Plants influence $\mathrm{N}$ cycling by controlling external $\mathrm{N}$ inputs to soils like deposition from the atmosphere via canopy properties (Schwarz et al. 2014) and losses like $\mathrm{N}$ leaching and $\mathrm{N}$ uptake (Knops et al. 2002). About 50 to $60 \%$ of plant-assimilated $\mathrm{N}$ in deciduous forests is annually returned to the soil via litterfall (Khanna et al. 2009). The associated flux of organic $C$ substrates is an important energy source for soil heterotrophs and therefore enhances soil organic matter formation and turnover (Knops et al. 2002; Kaiser et al. 2011). Although trees constitute the majority of the forest biomass, understory biomass has a strong influence on $\mathrm{N}$ fluxes which was ascribed to physiological and phenological differences between overstory and understory plants (Muller and Bormann 1976; Olsson and Falkengren-Grerup 2003; Schulze et al. 2009). While this implies a relationship with functional diversity, no study yet tested the influence of plant diversity in the canopy and the understory on $\mathrm{N}$ fluxes in organic layers. This is surprising given the positive relationship of plant diversity to $\mathrm{N}$ use efficiency in grasslands (Tilman et al. 1996; Kahmen et al. 2006) and to primary productivity and canopy $\mathrm{N}$ uptake in forests (Morin et al. 2011; Brassard et al. 2013; Schwarz et al. 2014).

In calcareous soils, which are widespread in Central Europe, biological activity is high resulting in high turnover rates of organic matter and a considerable contribution of soil microorganisms and animals to the mass of the organic layer (Scheu 1987; Frouz et al. 2013; Kammer et al. 2012). The dominant organic layer form is therefore mull consisting only of a fresh litter layer (Oi horizon) plus occasionally a thin fermented litter layer (Oe horizon) which are mineralized or incorporated into the mineral soil within less than one to a few years. The activity of soil organisms may thus strongly influence the $\mathrm{N}$ budget of organic layers. High gross $\mathrm{N}$ mineralization may for instance coincide with high $\mathrm{N}$ uptake of microorganisms at slightly acidic $\mathrm{pH}$ values (Kooijman et al. 2008) thereby reducing both the risk of $\mathrm{N}$ leaching and $\mathrm{N}$ availability for plants. However, bioturbation by the soil animals may stimulate and facilitate net $\mathrm{N}$ mineralization in European beech forests on calcareous soils and may counteract restricted plant $\mathrm{N}$ access (Scheu 1987; 1997; Verhoef and Brussaard 1990; Bardgett and Chan 1999).

Our objective was to identify controls of $\mathrm{N}$ leaching from organic layers in forests dominated by European beech by relating dissolved $\mathrm{N}$ inputs and outputs from 12 forests in two regions over three consecutive growing seasons to abiotic and biotic drivers. The study forests were exposed to a total $\mathrm{N}$ deposition from the atmosphere of about $15 \mathrm{~kg} \mathrm{ha}^{-1}$ year $^{-1}$ (Schwarz et al. 2014). We hypothesized that (1) gross $\mathrm{N}$ fluxes with litter leachate are dominated by throughfall-derived $\mathrm{N}$ while the contribution of organic layer mineralization is small, (2) the small contributions of organic layer mineralization to gross $\mathrm{N}$ fluxes in litter leachate are positively related with stand basal area (as a proxy for litterfall), (3) vascular plant diversity reduces dissolved $\mathrm{N}$ fluxes in organic layers, and (4) the soil fauna increases dissolved $\mathrm{N}$ fluxes in litter leachate by accelerating soil organic matter decomposition.

\section{Materials and Methods}

\section{Site description}

This study was conducted in the Schwäbische Alb $\left(48^{\circ}\right.$ $24^{\prime} \mathrm{N}, 9^{\circ} 24^{\prime} \mathrm{E} ; 740-788 \mathrm{~m}$ a.s.l.) and in Hainich-Dün $\left(51^{\circ} 10^{\prime} \mathrm{N}, 10^{\circ} 23^{\prime} \mathrm{E} ; 333\right.$ - $491 \mathrm{~m}$ a.s.l) in Germany. The two study regions are similar in climate, parent materials and soil types (Table 1) and represent typical conditions in Central European mid-mountain ranges. The organic layers consist of $\mathrm{Oi}$ and Oe horizons, except on one plot (AEW8) where a thin discontinuous Oa horizon was detected additionally. Total N deposition in the growing season 2010 was $17.1 \pm$ standard deviation (SD) $4.3 \mathrm{~kg} \mathrm{ha}^{-1}$ in the Schwäbische Alb and $13 \pm$ SD $2.5 \mathrm{~kg} \mathrm{ha}^{-1}$ in Hainich-Dün (Schwarz et al. 2014). 
In both regions, we investigated 6 forest plots $(100 \mathrm{~m}$ $\times 100 \mathrm{~m}$ ) dominated by European beech (i.e., $>70 \%$ of stand basal area). Other species in the tree and shrub layer comprised sycamore maple (Acer pseudoplatanus L.), hornbeam (Carpinus betulus L.), and European ash (Fraxinus excelsior L.). In some forests in the Schwäbische Alb, a few Norway spruce trees were admixed to beech. The herb layer harbored mainly Amaryllidaceae, Brassicaceae, Cyperaceae, Euphorbiaceae, Lamiaceae, Oxalidaceae, Poaceae, Ranunculaceae, Rubiaceae, and Violaceae families. Wild garlic (Allium ursinum L.) is the dominant herb in spring, especially in Hainich-Dün, and collapses in early summer.

\section{Sampling and chemical analysis}

Cumulative throughfall and litter leachate was collected fortnightly in the years 2010 to 2012 when daily mean temperatures were $>0^{\circ} \mathrm{C}$ and samples could be collected in liquid state (roughly from March to November; Table 1). For convenience, we refer to the sampling period as growing season. Because of differences in meteorological conditions, growing season length differed among regions and years with 266, 280 and 266 days in the Schwäbische Alb and 252, 266 and 238 days in Hainich-Dün for 2010, 2011 and 2012, respectively (Table 1). The plots were inaccessible due to frost or hunting at few planned sampling campaigns which could not be realized ( 1 of 58 in the Schwäbische Alb; 4 of 54 in Hainich-Dün) and samples from these campaigns were included in the following sampling. Because of the storage of the sample in the field for two weeks, which was unavoidable for technical reasons, we cannot fully exclude some $\mathrm{N}$ transformation during the collection. The extent of $\mathrm{N}$ transformations is, however, low over a period of 14 days when samples are protected from light and contamination with easily degradable carbohydrates (e.g., particulate organic matter) is reduced (Fern 1993). The design of the sampling devices was thus chosen to reduce significant $\mathrm{N}$ transformations. Other studies revealed that the majority of $\mathrm{N}$ transformations occurs after storage times longer than two weeks in the field (Michalzik et al. 1997). The composition of dissolved $\mathrm{N}$ in samples that were collected over 28 days might have changed though, most likely resulting in a transformation of $\mathrm{NH}_{4}^{+}-\mathrm{N}$ to DON. Nevertheless, we included these samples in our analysis as the number of sampling campaigns concerned was small.

Regional precipitation was calculated as the mean of data from two nearby stations of the German Weather Service (DWD, Offenbach, Germany; Schwäbische Alb: Sonnenbühl-Genkingen, Münsingen-Apfelstetten;
Hainich-Dün: Leinefelde, Mühlhausen-Windeberg). Throughfall was sampled with 20 funnel-type collectors (diameter of $0.12 \mathrm{~m}$; polyethylene) per forest site in a subplot $(20 \mathrm{~m} \times 20 \mathrm{~m}) 0.3 \mathrm{~m}$ above the soil surface. Because of the sampling height, our data is not directly comparable to other throughfall monitoring sites in Europe (e.g., ICP Forests level II plots; ICP Forests 2010). We selected this sampling height to account for canopy $\mathrm{N}$ exchange of understory plants in throughfall and not in litter leachate. Canopy interactions of plants smaller than the sampling height on $\mathrm{N}$ fluxes were, however, still not accounted for in the estimated throughfall fluxes. Samples were thoroughly checked for contamination with soil material by splashing in the field visually and discarded in case of evidence of contamination. Splashing was a minor problem because the soil was almost completely covered by litter. Furthermore, outlier tests of concentration data (see Calculation of water and element fluxes) were applied to remove potentially contaminated samples from the data. Throughfall collectors were wrapped with aluminum foil to prevent photochemical reactions and algae growth. Funnels were equipped with a $1.6 \mathrm{~mm}$ polyester mesh and a table-tennis ball to prevent contamination with coarse particulate matter and to minimize evaporation, respectively. Litter leachate was sampled with three circular zero-tension lysimeters (diameter of $0.2 \mathrm{~m}$, polyvinyl chloride, covered with a $1.6 \mathrm{~mm}$ polyester mesh) per site which were installed horizontally below the soil organic layer in summer 2009. Polyethylene hoses attached to the lysimeter outlet drained the collected sample into polyethylene bottles stored in the dark below ground. Between November 23, 2010 and January 18, 2011, snow melt water and litter leachate was collected continuously in forest plots of the Schwäbische Alb. Snow melt water was sampled with a rectangular snow lysimeter $\left(0.08 \mathrm{~m}^{2}\right.$, polypropylene) connected to polypropylene barrels.

During each sampling campaign, the volume of water in each collector was measured and a volume-weighted aliquot of each sample type per plot was taken in the field. All samples were filtered through pre-rinsed (at least $0.05 \mathrm{~L}$ distilled water and $0.05 \mathrm{~L}$ sample) folded paper filters (low N concentration, $5-8 \mu \mathrm{m}, 292$, Munktell \& Filtrak, Bärenstein, Germany, and Sartorius, Göttingen, Germany) and stored at $-18^{\circ} \mathrm{C}$ until chemical analysis.

Total dissolved nitrogen (TDN) concentrations were determined after catalytic oxidation with TOC/TN analyzers (Schwäbische Alb: Vario TOC cube, Elementar GmbH, Hanau, Germany; Hainich-Dün: VPCN, Shimadzu, Düsseldorf, Germany). Concentrations of $\mathrm{NH}_{4}{ }^{+}-\mathrm{N}$ and $\mathrm{NO}_{3}{ }^{-}-\mathrm{N}$ were determined photometrically after a modified Berthelot reaction and colorimetrically after $\mathrm{Cd}$ reduction to $\mathrm{NO}_{2}{ }^{-}$and reaction to 


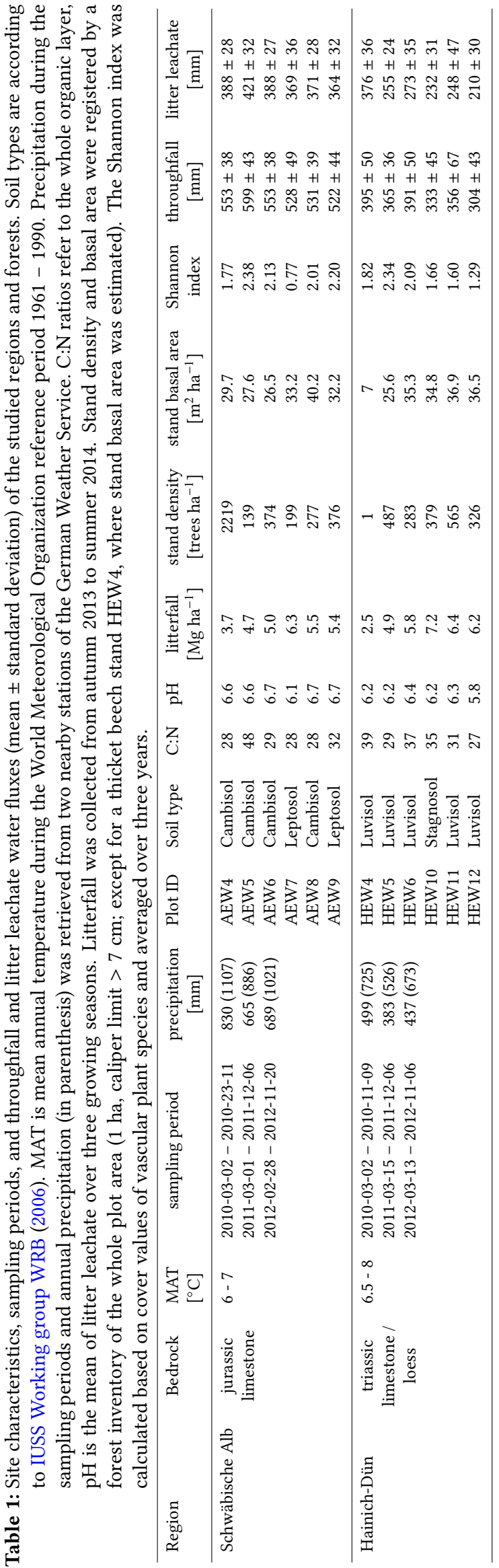

an azo-dye, respectively, with a continuous flow analyzer (AutoAnalyzer 3, Seal Analytical GmbH, Norderstedt, Germany). The concentrations of dissolved organic $\mathrm{N}(\mathrm{DON})$ were calculated as the difference between TDN and inorganic $\mathrm{N}$ forms. Concentrations of $\mathrm{Cl}^{-}$were determined with an ion-specific electrode (Orion 9417BN, Thermo Scientific, Nijkerk, The Netherlands).

\section{Forest and vegetation properties, arthropod biomass and organic layer properties}

Species and diameter at breast height (dbh; measured to the millimeter) of all trees with a dbh $\geq 7 \mathrm{~cm}$ growing on a plot were surveyed within two vegetation periods between September 2008 and April 2010, and used for the calculation of forest stand basal area. For plot AEW4 we used forest inventory data sampled in November 2012 because initial inventory at this site was incomplete due to high tree numbers. The basal area of forest plot HEW 4 was estimated based on a mean dbh of 3 to $4 \mathrm{~cm}$ and a stand density of 6000 to 10000 trees ha ${ }^{-1}$ because this stand is a thicket with only few individuals exceeding the caliper limit of the forest inventory (Schall and Ammer 2013). To validate our interpretation of a stand basal area effect on dissolved $\mathrm{N}$ fluxes with litter leachate, litterfall was collected from September 24, 2013 to June 03, 2014 in the Schwäbische Alb and from October 09, 2013 to June 17, 2014 in Hainich-Dün with 5 litterfall traps (sampling area of $0.25 \mathrm{~m}^{2}$ ) per plot. Litterfall mass was determined after drying at $60^{\circ} \mathrm{C}$ and removing coarse woody litter $(>20 \mathrm{~mm})$. For a sampling campaign in October 2014, the average coefficient of variation in litterfall mass among the 5 litterfall traps per forest plot was $25.7 \%$.

Vascular plant species richness of trees, shrubs (woody species, height $<5 \mathrm{~m}$ ) and herbs was determined annually in each forest in early summer between 2010 and 2012 in a $20 \mathrm{~m} \times 20 \mathrm{~m}$ subplot and plant diversity was quantified by the Shannon index $\left(H^{\prime}\right)$ according to Eq. 1.

$$
H^{\prime}=-\sum_{i=1}^{S} p_{i} \times \ln \left(p_{i}\right),
$$

where $S$ denotes the total number of vascular plant species present, $i$ identifies an individual species, and $p_{i}$ is the cover value of species $i$. Additionally, Shannon indexes were calculated individually for trees, shrubs and herbs. The Shannon indexes (using antilogarithm) and cover values were averaged over the study period.

Soil fauna was sampled to a depth of $0.05 \mathrm{~m}$ in spring 2008. Soil macrofauna and mesofauna was extracted by 
heat from two to four soil cores of $0.2 \mathrm{~m}$ and $0.05 \mathrm{~m}$ diameter, respectively. Lumbricidae were extracted separately in situ with a mustard solution (area $=0.25 \mathrm{~m}^{2}$ ). Soil fauna was determined to the species level, average weight per species was determined after drying at $60^{\circ} \mathrm{C}$ and mass-length regressions and population biomass in mg dry weight $\mathrm{m}^{-2}$ was calculated as detailed in Ehnes et al. (2014). For statistical analysis, soil fauna species were aggregated to the functional groups macro detritivores, including the taxonomic groups Coleoptera, $\mathrm{Di}$ plopoda, Isopoda, Lumbricidae, and Symphyla, and meso detritivores, including Collembola and Oribatida. Additionally, microbial biomass in a fresh subsample of the litter layer was determined by measuring maximum initial respiratory response (Anderson and Dom$\operatorname{sch} 1980)$.

Organic layers were sampled at 14 sampling points along two $36 \mathrm{~m}$ transects in each forest site using a rectangular metal frame of $0.15 \mathrm{~m}$ side length in May 2011. Organic layers were separated into horizons, and thickness and dry mass was recorded. For each horizon, composite subsamples dried at $70^{\circ} \mathrm{C}$ were analyzed for $\mathrm{C}$ and $\mathrm{N}$ concentrations with an elemental analyzer (Vario EL, Elementar). The C:N ratios of the organic layers were calculated as mass-weighted mean of all organic layer horizons.

\section{Calculation of water and element fluxes}

Water input into the soil was quantified by volumetric measurements of throughfall precipitation. Missing throughfall amounts were substituted by the average throughfall of the sampling period in the respective area (Schwäbische Alb: $1 \%$; Hainich-Dün: $5 \%$ of total sample number). We did not include stemflow fluxes because we believe that stemflow is of limited importance for the budget of the organic layers because it is spatially concentrated around trees where it causes erosion of the litter layer and thus infiltrates directly into the mineral soil at the base of trunks (Levia and Frost 2003). Furthermore, stemflow deposition of TDN in the growing season 2010 was only $0.27 \pm \mathrm{SD} 0.15 \mathrm{~kg} \mathrm{ha}^{-1}$ in the Schwäbische Alb and $0.71 \pm$ SD $0.28 \mathrm{~kg} \mathrm{ha}^{-1}$ in Hainich-Dün (Schwarz et al. 2014).

Water fluxes through organic layers cannot be inferred directly from the collected water amount by zerotension lysimeters because of the interface effect (i.e. the artificial barrier prevents water drainage until water saturation of the organic layer is reached). We thus used a two-step $\mathrm{Cl}^{-}$balance approach of throughfall and litter leachate to estimate water fluxes through the organic layer. Given sufficient water flow, $\mathrm{Cl}^{-}$is inert in soils (Beese and van der Ploeg 1979) and water flux can be calculated according to Eq. 2 .

$$
q_{L L}[\mathrm{~mm}]=q_{T F}[\mathrm{~mm}] \times C l_{T F}^{-} / C l_{L L}^{-},
$$

where $q_{L L}$ is the water flux through the organic layer, $q_{T F}$ is the throughfall precipitation, $C l_{T F}^{-}$and $C l_{L L}^{-}$is the $\mathrm{Cl}^{-}$concentration in throughfall and litter leachate, respectively. We then calculated a linear regression function of throughfall precipitation on water leaching through the organic layer for all available samples to infer water fluxes through the organic layer directly from throughfall precipitation $\left(\mathrm{R}^{2}=0.46\right)$. For this calculation, we excluded low and high precipitation sampling periods $\left(5 \mathrm{~mm}(14 \text { days })^{-1}<\right.$ throughfall $<80 \mathrm{~mm}(14$ days $)^{-1} ; 6 \%$ of available cases) to minimize $\mathrm{Cl}^{-}$imbalances because of transient retention and spontaneous release of $\mathrm{Cl}^{-}$and insufficient drainage of the lysimeters. The linear regression revealed an interception loss of $1.03 \mathrm{~mm}$ and a fractional water loss of throughfall precipitation due to evapotranspiration in the organic layer of $27 \%$ on a 14 days basis. These estimates are similar to values of interception and evapotranspiration in organic layers under European beech in Luxembourg (Gerrits et al. 2010).

Prior to flux calculations, we removed outliers that were outside $1.5 \times$ inter-quartile range of logtransformed concentrations for each plot and $\mathrm{N}$ form separately while accounting for seasonality patterns. In throughfall, $1.8 \%, 0.6 \%$ and $1.9 \%$, and in litter leachate, $0.6 \%, 1.2 \%$ and $0.6 \%$ of $\mathrm{TDN}, \mathrm{NH}_{4}^{+}-$ $\mathrm{N}$ and $\mathrm{NO}_{3}{ }^{-}-\mathrm{N}$ concentrations, respectively, were removed. These samples were probably contaminated (e.g., leaching from coarse debris or dead insects in the funnel of the collectors) and mostly matched for the three $\mathrm{N}$ forms. Missing concentrations were substituted by volume-weighted mean concentrations which were calculated for spring, summer and fall separately to account for seasonal concentration patterns. Because of insufficient sample volume, volume-weighted mean concentrations of $\mathrm{NH}_{4}{ }^{+}-\mathrm{N}$ and $\mathrm{NO}_{3}{ }^{-}-\mathrm{N}$ in litter leachate at HEW11 and HEW12 in spring 2011 could not be determined and were substituted by multiplying TDN concentration with the respective average fractional contribution of $\mathrm{NH}_{4}{ }^{+}-\mathrm{N}$ and $\mathrm{NO}_{3}{ }^{-}-\mathrm{N}$ to TDN in spring 2010 and 2012 at the same sites. Gross fluxes of TDN, $\mathrm{NH}_{4}{ }^{+}-\mathrm{N}$ and $\mathrm{NO}_{3}{ }^{-}-\mathrm{N}$ with throughfall and litter leachate were calculated by multiplying water flux with volume-weighted mean concentrations. Net fluxes of TDN, $\mathrm{NH}_{4}{ }^{+}-\mathrm{N}$ and $\mathrm{NO}_{3}{ }^{-}-\mathrm{N}$ in the organic layer were calculated by subtracting throughfall fluxes from gross fluxes in litter leachate of the respective $\mathrm{N}$ form.

To provide an estimate of unconsidered TDN fluxes in winter, we used the TDN concentration in snow melt water and litter-leachate collected over 56 days in the 
Schwäbische Alb. Unfortunately, the volume of snow melt water exceeded the capacity of the collection barrels and the collection was therefore not quantitative. Infiltration to the soil during winter was therefore estimated from regional precipitation depths at nearby stations of the German Weather Service (Table 1), assuming an interception, evaporation and sublimation loss of $20 \%$ which is in the lower range of sublimation losses reviewed by Molotch et al. (2011). Litter leachate water flux was assumed to equal the infiltration in winter. Fluxes in winter were not considered in the data analysis but were used to approximate the fraction of $\mathrm{N}$ leaching outside the growing season.

\section{Statistics}

Differences in throughfall precipitation and deposition among the growing seasons were tested for each region separately with an F-test followed by Tukey's honest significant difference test. Regional differences in throughfall volume and deposition, and water fluxes in the organic layer, were tested with a pairwise $t$-test grouped by growing season. Pearson's coefficient of correlation was used to test correlations among covariates.

Because our data represent repeated measures over time from the same plots, we used general least squares models including a first-order auto-regressive correlation structure to account for dependence among observations from the same site. Gross fluxes of TDN $\mathrm{NH}_{4}{ }^{+} \mathrm{N}, \mathrm{NO}_{3}{ }^{-}-\mathrm{N}$ and DON, and net fluxes of $\mathrm{NH}_{4}{ }^{+}$ $\mathrm{N}$ (absolute value; all original values negative) were log-transformed to obtain Gaussian distributed residuals. Model development was performed by stepwise backward selection from a beyond optimal model based on Aikaike's information criteria adjusted for small sample size (AICc) using maximum likelihood estimation. The initial models contained growing season, region, $\mathrm{C}: \mathrm{N}$ ratio of the organic layer, stand basal area (squared, for distributional reasons) as a proxy for tree biomass, the Shannon index of trees, shrubs and herbs, soil macro and meso fauna biomass, respectively, and a growing season $\times$ region interaction. Models of gross fluxes additionally included throughfall deposition (log-transformed) of the respective $\mathrm{N}$ form. No other interaction terms were included because coefficient estimates of interaction terms were correlated with the coefficient estimate of a main effect. We did not include estimates of microbial biomass because of collinearity with $\mathrm{C}: \mathrm{N}$ ratios as indicated by a variance inflation factor $\geq 10$. The $\mathrm{C}: \mathrm{N}$ ratio was preferred over microbial biomass as an explanatory variable because it integrates over both soil organic matter and soil microbes. Gaussian distribution and homogeneity were inspected with the Shapiro-Wilk test, diagnostic plots and the Bartlett test (for factors), respectively. The significance of effects was tested with analysis of covariance after refitting the model with restricted maximum likelihood estimation.

To analyze the relationship between fluxes of TDN and $\mathrm{NO}_{3}{ }^{-} \mathrm{-N}$ and plant diversity more closely, we refitted the optimal models after substitution of the Shannon index of all vascular plants by the individual Shannon index of the functional groups trees, shrubs and herbs. We further fitted models with cover values of functional plant groups instead of Shannon indices to differentiate between biomass and diversity effects.

\section{Results}

\section{Annual and regional variation of gross and net fluxes of dissolved $\mathrm{N}$}

Precipitation in the growing season 2010, 2011 and 2012 contributed $75.0 \%, 75.1$ and $67.5 \%$ to annual precipitation in the Schwäbische Alb and $68.8 \%, 72.8 \%$ and $64.9 \%$ in Hainich-Dün, respectively (Table 1). Throughfall precipitation in the growing seasons was higher in the Schwäbische Alb (552 \pm SD $44 \mathrm{~mm})$ than in HainichDün $(347 \pm$ SD $57 \mathrm{~mm} ; P<0.001)$. Throughfall composition was similar in the Schwäbische Alb (27.3 \pm SD $4.2 \%$ $\left.\mathrm{NH}_{4}{ }^{+}-\mathrm{N}, 52.0 \pm \mathrm{SD} 2.1 \% \mathrm{NO}_{3}{ }^{-}-\mathrm{N}, 20.7 \pm \mathrm{SD} 3.3 \% \mathrm{DON}\right)$ and in Hainich-Dün $\left(24.9 \pm \mathrm{SD} 4.8 \% \mathrm{NH}_{4}^{+}-\mathrm{N}, 55.3 \pm\right.$ SD $\left.4.9 \% \mathrm{NO}_{3}{ }^{-}-\mathrm{N}, 19.8 \pm \mathrm{SD} 3.2 \% \mathrm{DON}\right)$. Throughfall deposition in the Schwäbische Alb exceeded that in Hainich-Dün for all $\mathrm{N}$ forms $(P<0.05$; Fig. 1). Deposition of $\mathrm{NH}_{4}^{+}-\mathrm{N}$ with throughfall increased significantly in Hainich-Dün from 2010 to 2012 (Fig. 1b). In Hainich-Dün, throughfall deposition of $\mathrm{NO}_{3}{ }^{-}-\mathrm{N}$ in 2011 (Fig. 1c; $P<0.05)$ and of DON in $2012(P<0.01$, log-transformed; Fig. 1d) was lower compared with other growing seasons. There were no differences in $\mathrm{N}$ fluxes with throughfall among growing seasons in the Schwäbische Alb.

Gross fluxes of TDN with litter leachate were dominated by $\mathrm{NO}_{3}{ }^{-}-\mathrm{N}$ in the Schwäbische Alb $(62.8 \pm$ SD $8.6 \%)$ and in Hainich-Dün $(70.2 \pm$ SD $2.6 \%)$. The contribution of $\mathrm{NH}_{4}^{+}-\mathrm{N}$ to gross fluxes of TDN in litter leachate in the Schwäbische Alb (8.6 \pm SD $3.2 \%)$ and in Hainich-Dün $(6.5 \pm$ SD $3.0 \%)$ was lower than in throughfall. The fraction of DON in litter leachate was only slightly greater than in throughfall and similar in both regions (Schwäbische Alb: $28.5 \pm$ SD 9.5\%; Hainich-Dün: $23.3 \pm$ SD $3.1 \%$ ). In contrast to throughfall deposition and despite greater water fluxes in organic layers of the Schwäbische Alb (386 \pm SD $32 \mathrm{~mm})$ 
compared with Hainich-Dün $(241 \pm$ SD $40 \mathrm{~mm}$; $P<$ 0.001), gross fluxes of TDN and $\mathrm{NO}_{3}{ }^{-} \mathrm{N}$ with litter leachate were similar in both regions and varied only slightly among growing seasons (Table 2, Fig. 1a, c). Within regions, gross $\mathrm{NH}_{4}{ }^{+}-\mathrm{N}$ and DON fluxes varied significantly among the growing seasons (interaction term in Table 2). In 2010, gross $\mathrm{NH}_{4}^{+}-\mathrm{N}$ fluxes were an order of magnitude lower in Hainich-Dün than in the Schwäbische Alb (Fig. 1b). Likewise, gross DON fluxes were lower in Hainich-Dün than in the Schwäbische Alb in 2012 (Fig. 1d). Gross fluxes of all dissolved $\mathrm{N}$ forms in litter leachate except DON were correlated with the respective throughfall deposition (Table 2, Fig. 3a).

Net fluxes (i.e. throughfall - litter leachate) of TDN varied among the growing seasons (Table 2) and were greater in 2010 than in 2011 and 2012 (Fig. 2). Intraregional variation of net TDN (Schwäbische Alb: $-2.3 \pm$ SD $4.3 \mathrm{~kg} \mathrm{ha}^{-1}$; Hainich-Dün: $5.9 \pm$ SD $5.4 \mathrm{~kg} \mathrm{ha}^{-1}$ ) and net $\mathrm{NO}_{3}{ }^{-} \mathrm{N}$ fluxes (Schwäbische Alb: $0.1 \pm \mathrm{SD}$ $3.1 \mathrm{~kg} \mathrm{ha}^{-1}$; Hainich-Dün: $5.7 \pm \mathrm{SD} 4.0 \mathrm{~kg} \mathrm{ha}^{-1}$ ) was large rendering differences between regions insignificant (Table 2). In Hainich-Dün, however, net fluxes of TDN and $\mathrm{NO}_{3}{ }^{-}-\mathrm{N}$ were positive in all cases while both positive and negative net fluxes were observed in the Schwäbische Alb (Fig. 2). Net fluxes of $\mathrm{NH}_{4}^{+}$$\mathrm{N}$ with litter leachate decreased from to 2010 to 2012 and were generally negative (Fig. 2) indicating retention or transformation in organic layers. The temporal variation of net $\mathrm{NH}_{4}{ }^{+}-\mathrm{N}$ fluxes (Table 2) was related to the variation in throughfall $\mathrm{NH}_{4}{ }^{+}-\mathrm{N}$ deposition $(\mathrm{r}=-$ $0.73, P<0.001)$. Net fluxes of $\mathrm{NH}_{4}{ }^{+}-\mathrm{N}$ and DON were lower in the Schwäbische Alb than in Hainich-Dün (Table 2, Fig. 2). Similar to TDN and $\mathrm{NO}_{3}{ }^{-}-\mathrm{N}$, net fluxes of DON with litter leachate were positive in all forest plots in Hainich-Dün while both positive and negative DON net fluxes occurred in the Schwäbische Alb (Fig. 2).

Estimated TDN fluxes associated with snow melt and litter leachate in winter ranged 0.8 to $3.8 \mathrm{~kg} \mathrm{ha}^{-1}$ and 0.9 to $3.1 \mathrm{~kg} \mathrm{ha}^{-1}$ in the Schwäbische Alb, representing $10.5 \pm 5.3 \%$ and $13.2 \pm 5.2 \%$ of the annual TDN inputs $\left(16.3 \pm \mathrm{SD} 3.9 \mathrm{~kg} \mathrm{ha}^{-1}\right)$ and outputs $\left(16.0 \pm 8.1 \mathrm{~kg} \mathrm{ha}^{-1}\right)$ of the organic layer.

\section{Factors influencing gross and net fluxes of dissolved $\mathrm{N}$ during the growing season}

Stand basal area was positively related to gross and net fluxes of TDN, $\mathrm{NO}_{3}{ }^{-}-\mathrm{N}$ and DON (Table 2, Fig. 3c, d) suggesting that the source function of trees for dissolved $\mathrm{N}$ dominates over the sink function. In contrast, stand basal area was not correlated with gross and net fluxes of $\mathrm{NH}_{4}^{+}-\mathrm{N}$ (Table 2).
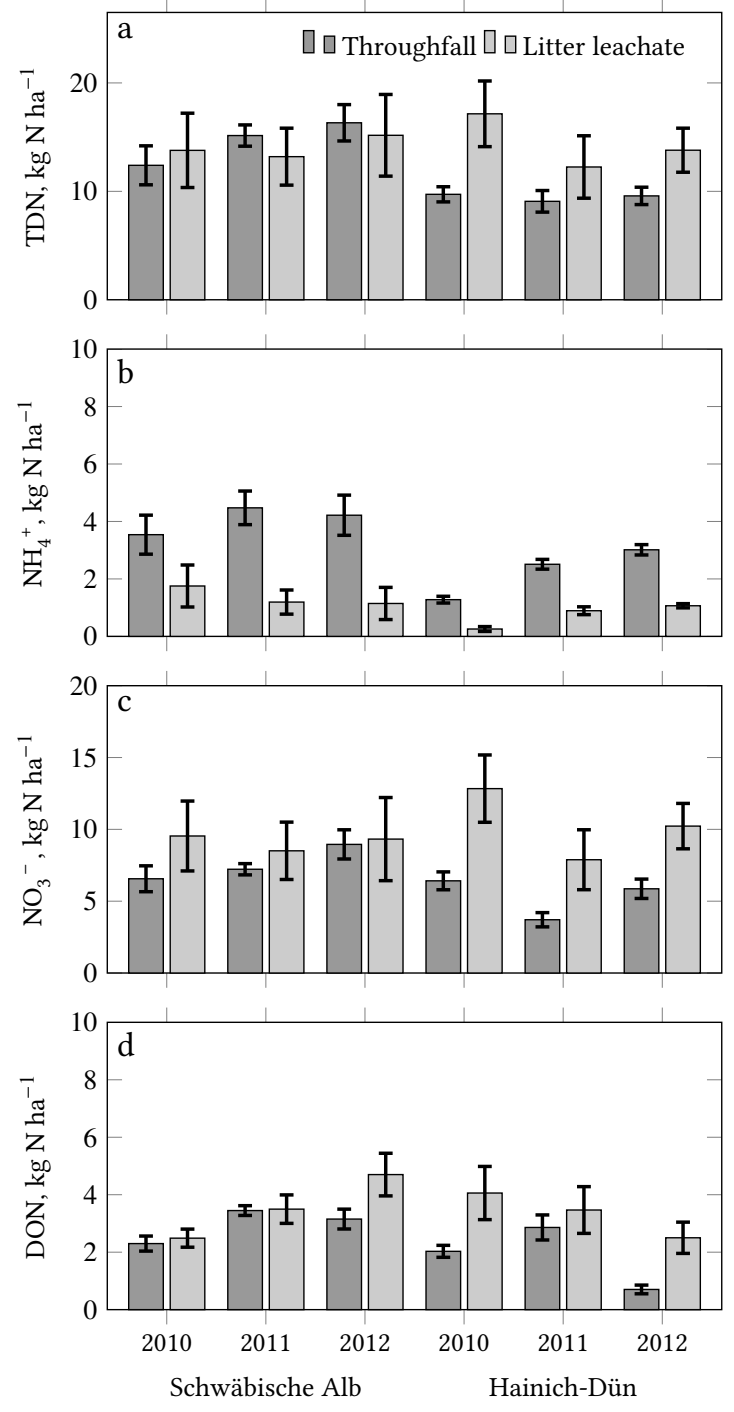

Fig. 1: Gross fluxes of total dissolved nitrogen (TDN; a), $\mathrm{NH}_{4}^{+}-\mathrm{N}(\mathrm{b}), \mathrm{NO}_{3}{ }^{-}-\mathrm{N}(\mathrm{c})$, and dissolved organic nitrogen (DON; d) with throughfall and litter leachate for the growing seasons 2010, 2011 and 2012 in the Schwäbische Alb ( $(n=6)$ and in Hainich-Dün $(n=6)$, respectively. Error bars indicate mean \pm standard error.

The Shannon index of vascular plants explained a significant fraction of the variation of gross and net fluxes of TDN and $\mathrm{NO}_{3}{ }^{-} \mathrm{N}$ in litter leachate (Table 2). Gross and net fluxes of TDN and $\mathrm{NO}_{3}{ }^{-}-\mathrm{N}$ both correlated negatively with the Shannon index (Fig. 3e, f). The Shannon index, however, did not explain a significant part of the variation in gross and net fluxes of $\mathrm{NH}_{4}{ }^{+}-\mathrm{N}$ and DON, respectively.

Separating the Shannon index into different plant functional groups indicated that the diversity effect on gross and net fluxes of TDN and $\mathrm{NO}_{3}{ }^{-} \mathrm{N}$ was mainly attributable to the diversity of herbaceous species (Table 3). Cover values of herbs were not correlated with 


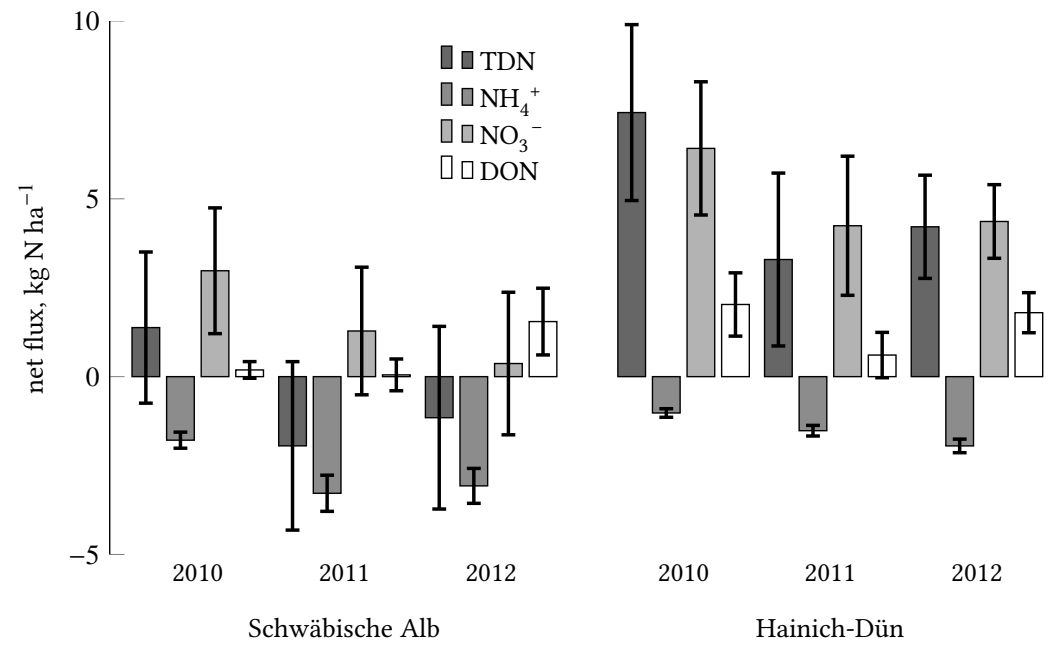

Fig. 2: Net fluxes of total dissolved nitrogen (TDN), $\mathrm{NH}_{4}{ }^{+}-\mathrm{N}, \mathrm{NO}_{3}{ }^{-}-\mathrm{N}$, and dissolved organic nitrogen (DON) through the organic layers in the growing seasons 2010 , 2011 and 2012 in the Schwäbische Alb $(\mathrm{n}=6)$ and HainichDün $(\mathrm{n}=6)$, respectively. Net fluxes were calculated as gross flux minus throughfall deposition of the respective $\mathrm{N}$ form and negative fluxes therefore indicate a loss or transformation during the passage through through the organic layer. Error bars indicate mean \pm standard error. stand basal area $(P=0.81)$ and did not explain variation of net and gross fluxes of TDN and $\mathrm{NO}_{3}{ }^{-} \mathrm{-N}$ (Table 4) suggesting that the diversity effect did not result from a diversity-biomass relationship. Cover values of trees were not correlated with stand basal area $(P=0.79)$ and explained an additional part of the variation in net fluxes of TDN and $\mathrm{NO}_{3}{ }^{-}-\mathrm{N}$ (Table 4).

While the biomass of macrofauna influenced net fluxes of $\mathrm{TDN}, \mathrm{NO}_{3}{ }^{-} \mathrm{N}$ and DON in litter leachate, mesofauna biomass explained part of the variation in both gross and net fluxes of TDN and $\mathrm{NO}_{3}{ }^{-} \mathrm{N}$ (Table 2). There was, however, no direct correlation of soil mesofauna biomass with fluxes of TDN and $\mathrm{NO}_{3}{ }^{-}-\mathrm{N}$ in litterleachate $(P>0.41)$ but soil mesofauna influenced gross and net fluxes of TDN and $\mathrm{NO}_{3}{ }^{-}-\mathrm{N}$ conditionally on other effects included in the model (Fig. 3g, h). Surprisingly, the C:N ratio of the organic layer was not a significant predictor of gross and net fluxes of TDN, $\mathrm{NH}_{4}^{+}-\mathrm{N}$, $\mathrm{NO}_{3}{ }^{-}-\mathrm{N}$, and DON in litter leachate, respectively. Likewise, microbial biomass was not correlated with the net and gross fluxes of dissolved $\mathrm{N}$ in litter leachate $(P>$ 0.29).

\section{Discussion}

\section{Change of $\mathrm{N}$ fluxes from throughfall to litter leachate}

Net leaching fluxes of dissolved $\mathrm{N}$ from organic layers were similar as reported for the Oi layer in a deciduous forest in Bavaria (-6.9 to $12.5 \mathrm{~kg} \mathrm{ha}^{-1}$ year $^{-1}$; Solinger et al. 2001). The range of positive and negative net fluxes indicated both the removal of throughfallderived dissolved $\mathrm{N}$ and a release of dissolved $\mathrm{N}$ from soil organic matter in the organic layers (Fig. 2). The conclusion differed with the considered $\mathrm{N}$ form with generally decreasing $\mathrm{NH}_{4}{ }^{+}-\mathrm{N}$ fluxes (by adsorption, microbial immobilization, plant uptake or nitrification) and increasing $\mathrm{NO}_{3}{ }^{-}-\mathrm{N}$ and DON fluxes (by mineralization, nitrification, and hydrolysis) from throughfall to litter leachate (Fig. 2). The correlation of gross fluxes of dissolved $\mathrm{N}$ in litter leachate with throughfall deposition suggested a partial throughflow of deposited $\mathrm{N}$, especially of $\mathrm{NO}_{3}{ }^{-}$(Table 2, Fig. 3a).

Although the studied organic layers did not indicate long-term accumulation of soil organic matter (i.e. formation of an Oa horizon), leaching of TDN (Fig. 2) was low representing $<10 \%$ of the typical aboveground litterfall of $63-75 \mathrm{~kg} \mathrm{~N} \mathrm{ha}^{-1}$ year $^{-1}$ in Central European beech forests (Khanna et al. 2009). Our budget is constrained to the growing season and thus misses processes occurring in winter. The estimate of TDN inputs and outputs to the organic layer in the Schwäbische Alb did not suggest that high $\mathrm{N}$ leaching rates occur in winter. The low estimated leaching in winter is in line with the observation that net $\mathrm{N}$ mineralization in $\mathrm{O}$ horizons and litter turnover is reduced in Central European deciduous forests in winter (Hentschel et al. 2008; Kammer et al. 2012). Likewise, winter accounted for 10 to $15 \%$ of annual net nitrification and $96 \%$ of deposited and soil produced $\mathrm{NO}_{3}{ }^{-}$was retained in soils in a hardwood forest in New Hampshire (Judd et al. 2007). Furthermore, microbial $\mathrm{N}$ immobilization is increased in autumn and winter because of greater $\mathrm{C}$ availability after litterfall (Kaiser et al. 2011), at least below snow and in phases in which the soil is not frozen which are common at the study sites in winter. Moreover, we did not quantify $\mathrm{N}$ transport into the mineral soil via biological mixing which is likely the dominant transport path for $\mathrm{N}$ into the mineral soil at our highly biologically active sites and accounts for most of the gap between quantified dissolved $\mathrm{N}$ exports from the organic layer and $\mathrm{N}$ addition by litterfall. 


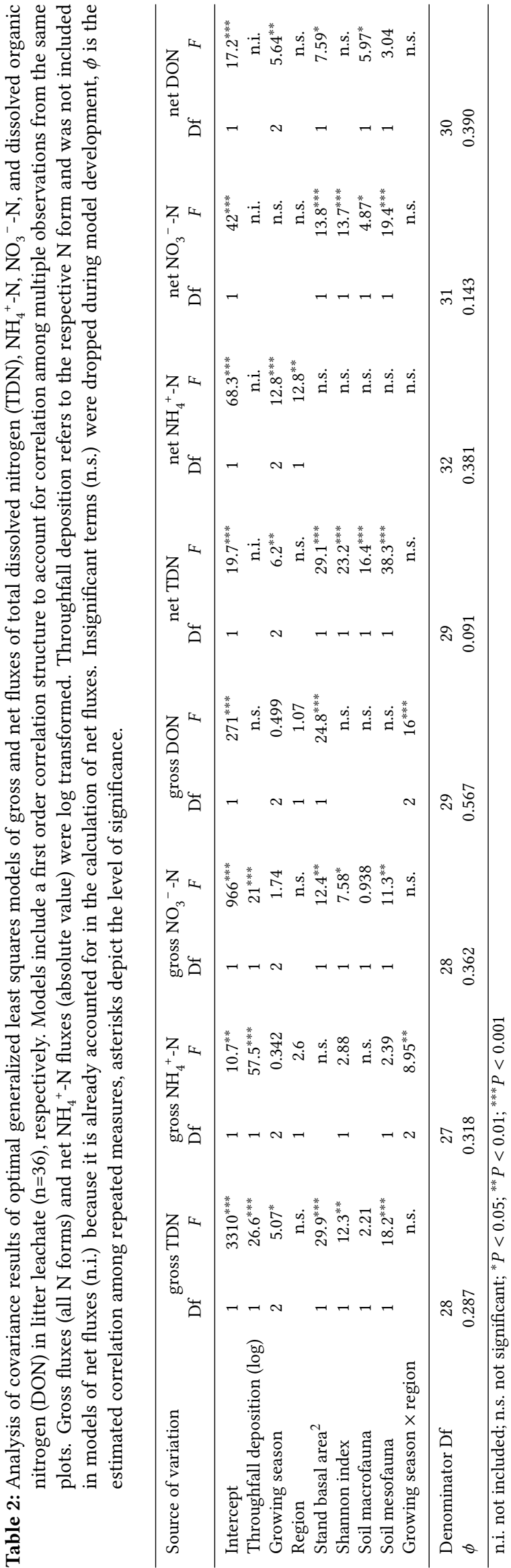

The C:N ratios of the studied organic layers (Table 1) did not explain a significant part of the variation in gross and net $\mathrm{N}$ fluxes because they were above the threshold value of 25 up to which a linear relationship with $\mathrm{N}$ leaching was described (MacDonald et al. 2002). Studies simulating deposition using isotope tracers revealed that organic layers are sinks for throughfall N. In a mixed hardwood stand in Massachusetts, highest recovery of applied tracers among ecosystem pools was found in Oi and Oa horizons (Nadelhoffer et al. 1999). In sugar-maple (Acer saccharum Marsh.) forests in Massachusetts, applied ${ }^{15} \mathrm{NO}_{3}{ }^{-}$was rapidly assimilated by the microbial community, subsequently released as $\mathrm{NH}_{4}^{+}-\mathrm{N}$, taken up by the plants, and accumulated in organic layers 6 years after the beginning of the treatment (Zak et al. 2008). In our study, throughfall $\mathrm{N}$ retention was more apparent in the Schwäbische Alb (where both positive and negative net fluxes of dissolved $\mathrm{N}$ with litter leachate were observed) than in Hainich-Dün (Fig. 2a, c). This corroborates with findings of Schwarz et al. (2014) who reported greater canopy N retention in the Schwäbische Alb than in Hainich-Dün and attributed this to insufficient root $\mathrm{N}$ uptake because of the shallow mineral soils in the Schwäbische Alb.

\section{Functional relationship between plants and dissolved $\mathbf{N}$ fluxes}

Stand basal area effect

Greater biomass (as approximated by stand basal area) coincided with greater gross and net fluxes of TDN, $\mathrm{NO}_{3}{ }^{-}-\mathrm{N}$ and DON (Fig. 3c, d) suggesting that trees are a source for $\mathrm{N}$ in litter leachate but also that the higher $\mathrm{N}$ availability in soil solution is a basis for higher growth. In contrast, stand basal area had no significant effect on fluxes of $\mathrm{NH}_{4}^{+}-\mathrm{N}$ (Table 2) probably because of strong immobilization and nitrification in the studied organic layers.

Trees contribute to $\mathrm{N}$ leaching from organic layers by providing above- and belowground litter for soil organic matter formation and $\mathrm{N}$ release during decomposition. Soluble N compounds are leached from litter immediately after senescence (Berg 2000). Litterfall mass as measured from October 2013 to June 2014 correlated closely with stand basal area $(\mathrm{r}=0.82, P=$ $0.001)$ and also with gross fluxes of TDN and $\mathrm{NO}_{3}{ }^{-}-\mathrm{N}$ $(\mathrm{r}=0.62, P>0.030)$. Furthermore, $\mathrm{C}$ and $\mathrm{N}$ stocks in the organic layer were positively correlated with basal area $(\mathrm{r}=0.70$ and $\mathrm{r}=0.65$, respectively, $P<0.05)$ but including $\mathrm{C}$ and $\mathrm{N}$ stocks did not improve the explanatory power of the models $(P>0.2$; Likelihood Test). While litter was an important source for $\mathrm{N}$ in litter leachate, 

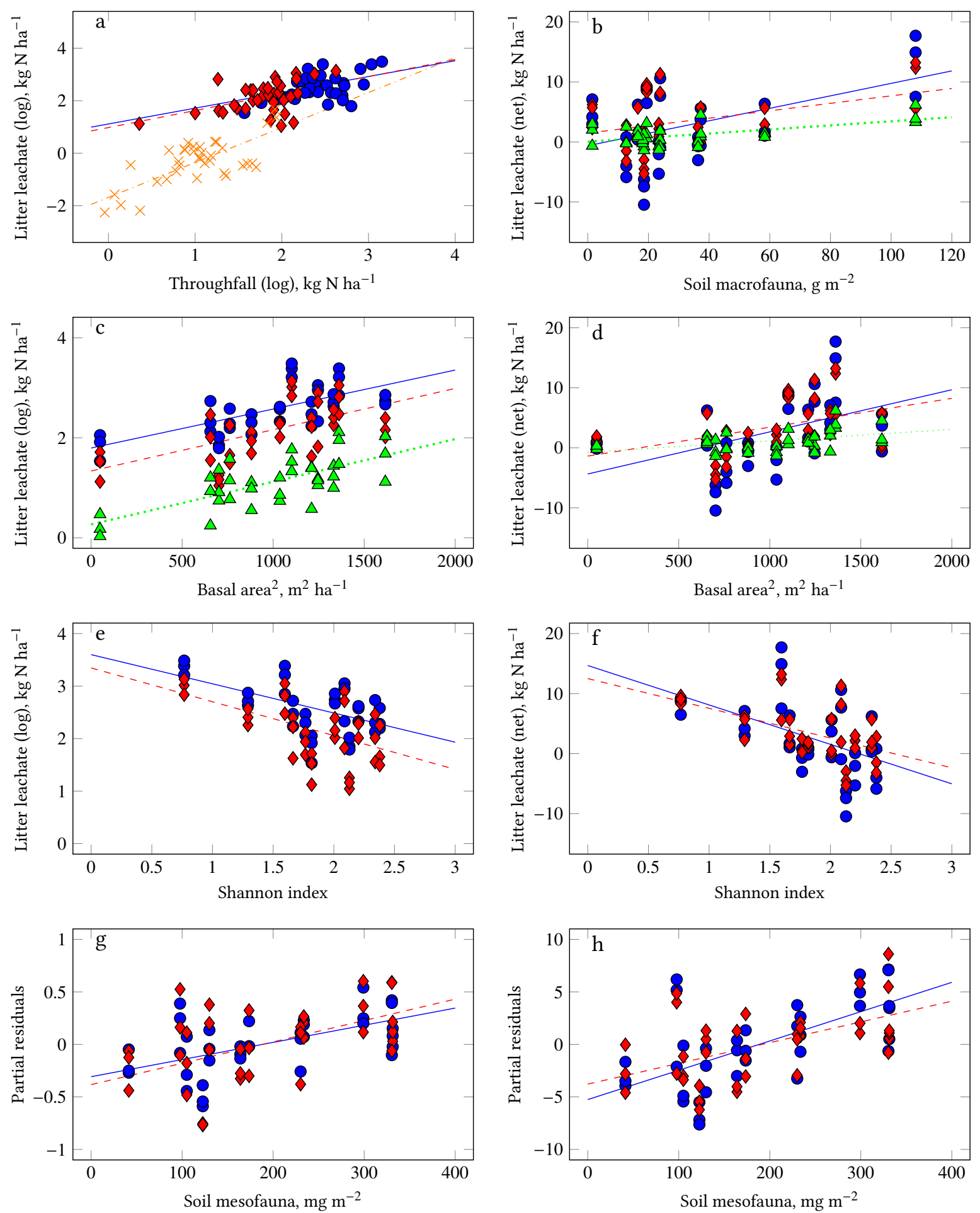

Fig. 3: Graphical representation of significant effects on gross (left column) and net fluxes (right column) of total dissolved nitrogen (TDN; blue circles), $\mathrm{NH}_{4}{ }^{+} \mathrm{N}$ (orange crosses), $\mathrm{NO}_{3}{ }^{-} \mathrm{-N}$ (red diamonds), and dissolved organic nitrogen (DON; green triangles) with litter leachate according to the optimal models as presented in Table 2. The effect of the soil mesofauna is visualized as a partial regression according to the model structure in Table 2 because of an insignificant direct relationship. Solid (TDN), dotdashed $\left(\mathrm{NH}_{4}{ }^{+} \mathrm{N}\right)$, dashed $\left(\mathrm{NO}_{3}{ }^{-} \mathrm{N}\right)$, and dotted (DON) lines represent regression estimates including an autoregressive correlation structure to account for dependence among multiple observations from the same site. 
Table 3: Analysis of covariance results of re-fitted generalized least squares models of gross and net fluxes of total dissolved nitrogen (TDN) and $\mathrm{NO}_{3}{ }^{-}-\mathrm{N}$ in litter leachate $(\mathrm{n}=36)$, respectively. Models correspond to the models presented in Table 2 but the Shannon index of vascular plants was substituted by the Shannon index of the functional groups trees, shrubs and herbs. Throughfall deposition refers to the respective $\mathrm{N}$ form and was not included in models of net fluxes (n.i.) because it is already accounted for in the calculation of net fluxes. Insignificant terms (n.s.) were dropped during original model development, $\phi$ is the estimated correlation among repeated measures and asterisks depict the level of significance.

\begin{tabular}{|c|c|c|c|c|c|c|c|c|}
\hline \multirow[t]{2}{*}{ Source of variation } & \multicolumn{2}{|c|}{ gross TDN } & \multicolumn{2}{|c|}{ gross $\mathrm{NO}_{3}^{-}-\mathrm{N}$} & \multicolumn{2}{|c|}{ net TDN } & \multicolumn{2}{|c|}{ net $\mathrm{NO}_{3}{ }^{-}-\mathrm{N}$} \\
\hline & Df & $F$ & Df & $F$ & Df & $F$ & Df & $F$ \\
\hline Intercept & 1 & $3545^{* * *}$ & 1 & $1582^{* * *}$ & 1 & $19^{* * *}$ & 1 & $49.1^{* * *}$ \\
\hline Throughfall deposition (log) & 1 & $28.3^{* * *}$ & 1 & $27.1^{* * *}$ & & n.i. & & n.i. \\
\hline Growing season & 2 & $5.11^{*}$ & 2 & 1.96 & 2 & $6.15^{* *}$ & & n.s. \\
\hline Stand basal area ${ }^{2}$ & 1 & $32.1^{* * *}$ & 1 & $21.1^{* * *}$ & 1 & $28^{* * *}$ & 1 & $16.2^{* * *}$ \\
\hline Shannon index trees & 1 & 2.36 & 1 & $4.85^{*}$ & 1 & $8.29^{* *}$ & 1 & $6.78^{*}$ \\
\hline Shannon index shrubs & 1 & 1.27 & 1 & 0.0914 & 1 & $7.79^{* *}$ & 1 & 2.08 \\
\hline Shannon index herbs & 1 & $12.9^{* *}$ & 1 & $13.2^{* *}$ & 1 & $18.6^{* * *}$ & 1 & $14.4^{* * *}$ \\
\hline Soil macrofauna & 1 & 1.85 & 1 & 0.173 & 1 & $10.3^{* *}$ & 1 & 2.17 \\
\hline Soil mesofauna & 1 & $19.2^{* * *}$ & 1 & $22.1^{* * *}$ & 1 & $31.3^{* * *}$ & 1 & $22.9^{* * *}$ \\
\hline Denominator Df & 26 & & 26 & & 27 & & 29 & \\
\hline$\phi$ & 0.263 & & 0.165 & & 0.107 & & 0.070 & \\
\hline
\end{tabular}

n.i. not included; n.s. not significant; ${ }^{*} P<0.05 ;{ }^{* *} P<0.01 ;{ }^{* * *} P<0.001$

fresh litter can also act as a sink for $\mathrm{N}$ released during decomposition (Berg 2000; Gebauer et al. 2000; Scheu 1997). Furthermore, the slow decomposition rates of beech litter (De Vries et al. 2006; Vesterdal et al. 2008) may additionally have limited $\mathrm{N}$ leaching from the organic layer.

The carbon flux associated with litterfall could also have fed back on the microbial and the decomposer community thereby affecting $\mathrm{N}$ fluxes indirectly (Knops et al. 2002). In a beech forest in Austria, C supply by litterfall increased microbial $\mathrm{N}$ immobilization in winter. The $\mathrm{N}$ stored in microbial biomass was released in the following growing season when $\mathrm{C}$ availability for microbes decreased (Kaiser et al. 2011). The authors reported that one third of annual plant $\mathrm{N}$ demand was resupplied by this process. However, microbial biomass was not correlated with gross and net fluxes of $\mathrm{N}$ in our study.

The role of the ground vegetation diversity for $\mathrm{N}$ fluxes

Gross and net fluxes of TDN and $\mathrm{NO}_{3}{ }^{-}-\mathrm{N}$ decreased with increasing plant diversity (Fig. 3e, f) which indicates either a decrease in the source (i.e. $\mathrm{N}$ release during decomposition) or an increase in the sink function (i.e. plant $\mathrm{N}$ uptake) of vascular plants in diverse communities. Decreased N release during decomposition seems unlikely because several studies on the re- lationship between plant diversity and organic matter turnover reported no or a positive effect of plant diversity on $\mathrm{N}$ release (e.g., Blair et al. 1990; Wardle et al. 1997; Fornara et al. 2009; Rosenkranz et al. 2012). Lower dissolved $\mathrm{N}$ fluxes in more diverse forests could instead have resulted from increased $\mathrm{N}$ demand of the vegetation as related to the greater productivity of more diverse forests (Morin et al. 2011; Paquette and Messier 2011; Brassard et al. 2013). However, forest biomass consists largely of trees which had an opposing effect in our study (Fig. 3c, d) and cover values of herbs and shrubs, as a surrogate for understory biomass, were poorly related with dissolved $\mathrm{N}$ fluxes (Table 4). Fluxes of TDN and $\mathrm{NO}_{3}{ }^{-}-\mathrm{N}$ with litter leachate therefore could instead have been affected by diversity effects like complementary $\mathrm{N}$ uptake through facilitation and functional, spatial and temporal niche partitioning. Because some herbs were smaller than the throughfall collectors, the decreasing effect of herb diversity on net TDN and $\mathrm{NO}_{3}{ }^{-}-\mathrm{N}$ fluxes could also have partly been attributable to canopy uptake in the herb layer.

The $\mathrm{N}$ release during litter decomposition differs among functional plant groups because leaf traits like $\mathrm{N}$ and lignin concentrations impact both litter decomposition and $\mathrm{N}$ immobilization (Wardle et al. 1997; Berg 2000). Functional traits other than growth form (e.g., leaf $\mathrm{N}$, nitrate reductase activity) were not determined in the studied communities and could thus not be examined directly. In temperate forests, understory plants 
Table 4: Analysis of covariance results of re-fitted generalized least squares models of gross and net fluxes of total dissolved nitrogen (TDN) and $\mathrm{NO}_{3}{ }^{-} \mathrm{N}$ in litter leachate $(\mathrm{n}=36)$, respectively. Models correspond to the models presented in Table 2 but the Shannon index of vascular plants was substituted by the cover values of the functional groups trees, shrubs and herbs. Throughfall deposition refers to the respective $\mathrm{N}$ form and was not included in models of net fluxes (n.i.) because it is already accounted for in the calculation of net fluxes. Insignificant terms (n.s.) were dropped during original model development, $\phi$ is the estimated correlation among repeated measures and asterisks depict the level of significance.

\begin{tabular}{|c|c|c|c|c|c|c|c|c|}
\hline \multirow[t]{2}{*}{ Source of variation } & \multicolumn{2}{|c|}{ gross TDN } & \multicolumn{2}{|c|}{ gross $\mathrm{NO}_{3}{ }^{-}-\mathrm{N}$} & \multicolumn{2}{|c|}{ net TDN } & \multicolumn{2}{|c|}{ net $\mathrm{NO}_{3}{ }^{-}-\mathrm{N}$} \\
\hline & Df & $F$ & Df & $F$ & Df & $F$ & Df & $F$ \\
\hline Intercept & 1 & $1879^{* * *}$ & 1 & $808^{* * *}$ & 1 & $9.49^{* *}$ & 1 & $23.6^{* * *}$ \\
\hline Throughfall deposition (log) & 1 & $16.1^{* * *}$ & 1 & $19.7^{* * *}$ & & n.i. & & n.i. \\
\hline Growing season & 2 & $5.01^{*}$ & 2 & 1.71 & 2 & $5.8^{* *}$ & & n.s. \\
\hline Stand basal area ${ }^{2}$ & 1 & $10.3^{* *}$ & 1 & $9.93^{* *}$ & 1 & $12.1^{* *}$ & 1 & $7.63^{* *}$ \\
\hline Cover value trees & 1 & 2.23 & 1 & 2.84 & 1 & $6.28^{*}$ & 1 & $4.63^{*}$ \\
\hline Cover value shrubs & 1 & 0.0624 & 1 & 1.39 & 1 & 0.457 & 1 & 0.223 \\
\hline Cover value herbs & 1 & 0.00963 & 1 & 0.232 & 1 & 0.0471 & 1 & 0.626 \\
\hline Soil macrofauna & 1 & 0.67 & 1 & 0.275 & 1 & 2.07 & 1 & 0.575 \\
\hline Soil mesofauna & 1 & $14.1^{* * *}$ & 1 & $12.7^{* *}$ & 1 & $18.5^{* * *}$ & 1 & $13.2^{* *}$ \\
\hline Denominator Df & 26 & & 26 & & 27 & & 29 & \\
\hline$\phi$ & 0.486 & & 0.431 & & 0.446 & & 0.397 & \\
\hline
\end{tabular}

n.i. not included; n.s. not significant; ${ }^{*} P<0.05 ;{ }^{* *} P<0.01 ;{ }^{* * *} P<0.001$

like herbs usually produce N-rich litter (Schulze et al. 2009). While the decomposition of wild garlic increased $\mathrm{N}$ leaching losses from temperate forests (Jandl et al. 1997), beech litter instead reduced $\mathrm{NO}_{3}{ }^{-} \mathrm{-N}$ leaching compared to control and nettle (Urtica dioica L.) litter treatments (Scheu 1997). A basic functional relationship between plant diversity and dissolved $\mathrm{N}$ fluxes in the studied forests could therefore reflect the buffering of $\mathrm{N}$ release from $\mathrm{N}$-rich litter or soil organic matter by $\mathrm{N}$ transfer to litter with lower $\mathrm{N}$ concentration (Berg 2000; Xiong et al. 2014).

Despite its low biomass compared to the tree layer, the understory of temperate forests has a great nitrogen retention capacity (Schulze et al. 2009) and is highly efficient in taking up throughfall-derived N (Gebauer et al. 2000). Furthermore, the understory in northern hardwood forests can act as a sink for $\mathrm{N}$ and reduces $\mathrm{N}$ leaching at the end of the dormant season when nitrification rates are high and tree demand is still low (Muller and Bormann 1976). The N release associated with the decomposition of herbaceous litter in the later growing season may have been buffered by tree uptake or immobilization in tree litter. With respect to the observed diversity effect, the 'vernal dam' hypothesis (Muller and Bormann 1976) may be translated into temporal, spatial and functional niche partitioning and facilitation. Spatial niche complementarity would most likely be related to rooting traits. In boreal forests, fineroot productivity increased with tree species evenness by more horizontal and vertical space filling in the or- ganic layer in mixtures of deep-rooting and shallowrooting species (Brassard et al. 2013). Additional functional niche partitioning would be related to the preference and ability of various plant species and their mycorrhizal associations to use different $\mathrm{N}$ forms. For instance, $\mathrm{NO}_{3}{ }^{-}-\mathrm{N}$ leaching was negatively correlated with understory biomass in Swedish oak forests because of the high nitrate reductase activity in this stratum (Olsson and Falkengren-Grerup 2003). Our results suggest, however, that the diversity and not only biomass or the mere presence of understory plants decreases $\mathrm{N}$ leaching in forest soils (Table 3, Table 4). Different mycorrhizal associations of plant species (e.g., ectomycorrhiza in beech, arbuscular mycorrhiza in ash, maple, herbs and grasses) potentially further increased resource use of $\mathrm{N}$ in more diverse forests.

\section{Effects of soil fauna on $\mathrm{N}$ fluxes}

Soil macrofauna biomass increased gross and net fluxes of TDN, $\mathrm{NO}_{3}{ }^{-}-\mathrm{N}$ and DON in litter leachate (Fig. 3b) likely through leaching from fecal pellets, stimulation and facilitation of mineralization, and structural changes in the organic layers induced by bioturbation. The soil macrofauna comprised mainly earthworms in this study. Bioturbation by earthworms increased N leaching probably by promoting the decomposition and mineralization of litter (Scheu 1987; Frouz et al. 2013). Furthermore, the burrowing activity of 
earthworms could have resulted in a higher throughflow rate of throughfall $\mathrm{N}$, reducing the residence time and availability for microorganisms of throughfall $\mathrm{N}$, respectively, and facilitated decomposition by increasing porosity and aeration, respectively (Curry and Schmidt 2007). In line with the observed relationship between soil macrofauna and net $\mathrm{NO}_{3}{ }^{-} \mathrm{N}$ fluxes (Table 2, Fig. 3b), short-term laboratory studies indicated a positive effect of earthworms on nitrification in soils containing beech litter (Scheu 1997). While the effect diminished in mixed litter treatments (beech, nettle) because of $\mathrm{N}$ transfer among litter species, other studies reported increased mineralization and leaching due to mixing of soil organic matter and mineral soil (Hector et al. 2000; Xiong et al. 2014).

The subsequent decomposition of fragmented litter by soil mesofauna might have further increased $\mathrm{N}$ mineralization and increased the availability of litter-derived C for microorganisms (Verhoef and Brussaard 1990; Jandl et al. 1997; Chamberlain et al. 2006). The latter potentially contributes to the seasonality of microbial $\mathrm{N}$ dynamics in beech forests (Kaiser et al. 2011). In a factorial microcosm experiment, the presence of Collembola, the most abundant mesofauna group in our study, increased $\mathrm{N}$ mineralization, $\mathrm{NO}_{3}{ }^{-}$leaching and plant $\mathrm{N}$ uptake (Bardgett and Chan 1999). The effect of soil mesofauna on dissolved $\mathrm{N}$ fluxes in litter leachate was only significant conditional on other covariates (Fig. 3g, h) suggesting an indirect relationship, possibly because of trophic interactions. In addition, Collembola grazing on fungi (Pollierer et al. 2007) could have decreased fungal $\mathrm{N}$ immobilization or stimulated mineralization of $\mathrm{N}$-rich fungal biomass after digestion and excretion. However, our results suggest that soil mesofauna biomass is an important control for plant $\mathrm{N}$ availability in forests where net $\mathrm{N}$ mineralization is assumed to be low.

\section{Conclusions}

- Decreasing fluxes of $\mathrm{NH}_{4}^{+}-\mathrm{N}$ and slightly increasing fluxes of $\mathrm{NO}_{3}{ }^{-}-\mathrm{N}$ and DON from throughfall to litter leachate in beech forests on calcareous soil can probably be attributed to high microbial $\mathrm{N}$ immobilization in organic layers with a high $\mathrm{C}: \mathrm{N}$ ratio.

- Dissolved $\mathrm{N}$ release from organic layers increased with forest basal area probably because of greater litterfall and resource availability.

- N leaching increased with soil fauna biomass possibly by stimulation and facilitation of mineralization.
- N leaching decreased with increasing plant diversity either because of decreasing $\mathrm{N}$ release during decomposition or through complementary $\mathrm{N}$ use particularly in the understory.

\section{Acknowledgements}

We thank the managers of the three Exploratories, Kirsten Reichel-Jung, Swen Renner, Katrin Hartwich, Sonja Gokkel, Kerstin Wiesner, and Martin Gorke for their work in maintaining the plot and project infrastructure; Christiane Fischer and Simone Pfeiffer for giving support through the central office, Michael Owonibi for managing the central data base, Markus Fischer, Eduard Linsenmair, Dominik Hessenmöller, Jens Nieschulze, Daniel Prati, François Buscot, Wolfgang W. Weisser and the late Elisabeth Kalko for their role in setting up the Biodiversity Exploratories project; and Jörg Hailer for providing forest stand information. We thank Bernhard Eitzinger, Melanie M. Maraun, Georgia Erdmann, Roswitha B. Ehnes, Christoph Digel and David Ott for contributing soil animal biomass data. We thank two anonymous reviewers for their valuable comments on an earlier version of this manuscript. The work has been funded by the DFG Priority Program 1374 "Infrastructure-Biodiversity-Exploratories" (Mi 927/2-2, Si 1106/4-2, Wi1601/12-2). Field work permits were issued by the responsible state environmental offices of Baden-Württemberg and Thüringen (according to $§ 72 \mathrm{Bbg}$ NatSchG).

\section{References}

Anderson JPE, Domsch KH (1980) Quantities of plant nutrients in the microbial biomass of selected soils. Soil Sci 130:211-216, doi:10.1097/00010694-198010000-00008

Bardgett RD, Chan KF (1999) Experimental evidence that soil fauna enhance nutrient mineralization and plant nutrient uptake in montane grassland ecosystems. Soil Biol Biochem 31:1007-1014, doi:10.1016/S0038-0717(99)00014-0

Beese F, van der Ploeg RR (1979) Simulation des AnionenTransports in ungestörten Bodensäulen unter stationären Fließbedingungen. Z Pflanzenernähr Bodenkd 142:69-85, doi:10.1002/jpln.19791420108

Berg B (2000) Litter decomposition and organic matter turnover in northern forest soils. For Ecol Manage 133:1322, doi:10.1016/S0378-1127(99)00294-7

Blair B, Parmalee R, Beare M (1990) Decay rates, nitrogen fluxes and decomposer communities of singleand mixed-species foliar litter. Ecology 71:1976-1985, doi:10.2307/1937606

Brassard BW, Chen HYH, Cavard X, Laganiére J, Reich PB, Bergeron Y, Paré D, Yuan Z (2013) Tree species diversity increases fine root productivity through increased 
soil volume filling. J Ecol 101:210-219, doi:10.1111/13652745.12023

Brumme R, Khanna PK (2008) Ecological and site historical aspects of $\mathrm{N}$ dynamics and current $\mathrm{N}$ status in temperate forests. Global Change Biol 14:125-141, doi:10.1111/j.13652486.2007.01460.x

Chamberlain PM, McNamara NP, Chaplow J, Stott AW, Black HIJ (2006) Translocation of surface litter carbon into soil by Collembola. Soil Biol Biochem 38:2655-2664, doi:10.1016/j.soilbio.2006.03.021

Curry JP, Schmidt O (2007) The feeding ecology of earthworms - a review. Pedobiologia 50:463-477, doi:10.1016/j.pedobi.2006.09.001

De Vries W, Reinds GJ, Gundersen P, Sterba H (2006) The impact of nitrogen deposition on carbon sequestration in European forests and forest soils. Global Change Biol 12:1151-1173, doi:10.1111/j.1365-2486.2006.01151.x

Durka W, Schulze ED, Gebauer G, Voerkeliust S (1994) Effects of forest decline on uptake and leaching of deposited nitrate determined from ${ }^{15} \mathrm{~N}$ and ${ }^{18} \mathrm{O}$ measurements. Nature 372:765-767, doi:10.1038/372765a0

Ehnes RB, Pollierer MM, Erdmann G, Klarner B, Eitzinger B, Digel C, Ott D, Maraun M, Scheu S, Brose U (2014) Lack of energetic equivalence in forest soil invertebrates. Ecology 95:527-537, doi:10.1890/13-0620.1

Fern M (1993) Throughfall measurements of nitrogen and sulphur compounds. Intern J Anal Chem 50:29-43, doi:10.1080/03067319308027581

Fornara D, Tilman D, Hobbie S (2009) Linkages between plant functional composition, fine root processes and potential soil $\mathrm{N}$ mineralization rates. J Ecol 97(1):48-56, doi:10.1111/j.1365-2745.2008.01453.x

Frouz J, Livečková $\mathrm{M}$, Albrechtová J, Chroňáková $\mathrm{A}, \mathrm{Ca}-$ jthaml T, Pižl V, Háněl L, Stary̌ J, Baldrian P, Lhotáková Z, Šimáčková H, Cepáková Š (2013) Is the effect of trees on soil properties mediated by soil fauna? A case study from post-mining sites. For Ecol Manage 309:87-95, doi:10.1016/j.foreco.2013.02.013

Gebauer G, Zeller B, Schmidt G, May C, Buchmann N, ColinBelgrand M, Dambrine E, Martin F, Schulze ED, Bottner P (2000) The fate of ${ }^{15} \mathrm{~N}$-labelled nitrogen inputs to coniferous and broadleaf forests. In: Schulze ED (ed) Carbon and nitrogen cycling in European Forest Ecosystems, Ecological Studies, vol 142, Springer-Verlag, Berlin, Heidelberg, pp $144-170$

Gerrits AMJ, Pfister L, Savenije HHG (2010) Spatial and temporal variability of canopy and forest floor interception in a beech forest. Hydrol Proc 24:3011-3025, doi:10.1002/hyp.7712

Hector A, Beale AJ, Minns A, Otway SJ, Lawton JH (2000) Consequences of the reduction of plant diversity for litter decomposition: effects through litter quality and microenvironment. Oikos 90:357-371, doi:10.1034/j.16000706.2000.900217.x
Hentschel K, Borken W, Matzner E (2008) Repeated freezethaw events affect leaching losses of nitrogen and dissolved organic matter in a forest soil. J Plant Nutr Soil Sci 171:699-706, doi:10.1002/jpln.200700154

ICP Forests (2010) Manual on methods and criteria for harmonized sampling, assessment, monitoring and analysis of the effects of air pollution on forests. UNECE, ICP Forests, Hamburg, Germany. URL: http://www.icpforests.org/Manual.htm

IUSS Working group WRB (2006) Guidelines for soil description, 4th edn. Food and Agricultural Organisation of the United Nations, Rome

Jandl R, Kopeszki H, Glatzel G (1997) Effect of a dense Allium ursinum (L.) ground cover on nutrient dynamics and mesofauna of a Fagus sylvatica (L.) woodland. Plant Soil 189:245-255, doi:10.1023/A:1004223011834

Judd KE, Likens GE, Groffman PM (2007) High nitrate retention during winter in soils of the Hubbard Brook Experimental Forest. Ecosystems 10:217-225, doi:10.1007/s10021$007-9027-x$

Kahmen A, Renker C, Unsicker SB, Buchmann N (2006) Niche complementarity for nitrogen: an explanation for the biodiversity and ecosystem functioning relationship? Ecology 87:1244-1255, doi:10.1890/00129658(2006)87[1244:NCFNAE]2.0.CO;2

Kaiser C, Fuchslueger L, Koranda M, Gorfer M, Stange CF, Kitzler B, Rasche F, Strauss J, Sessitsch A, ZechmeisterBoltenstern S, Richter A (2011) Plants control the seasonal dynamics of microbial $\mathrm{N}$ cycling in a beech forest soil by belowground C allocation. Ecology 92:1036-1051, doi:10.1890/10-1011.1

Kammer A, Schmidt MW, Hagedorn F (2012) Decomposition pathways of ${ }^{13} \mathrm{C}$-depleted leaf litter in forest soils of the Swiss Jura. Biogeochemistry 108:395-411, doi:10.1007/s10533-011-9607-x

Khanna P, Fortmann H, Meesenburg H, Eichhorn J, Meiwes K (2009) Biomass and element content of foliage and aboveground litterfall on the three long-term experimental beech sites: dynamics and significance. In: Brumme R, Khanna PK (eds) Functioning and Management of European Beech Ecosystems, Ecological Studies, vol 208, Springer-Verlag, Berlin, Heidelberg, pp 183-205

Knops JMH, Bradley KL, Wedin DA (2002) Mechanisms of plant species impacts on ecosystem nitrogen cycling. Ecol Lett 5:454-466, doi:10.1046/j.1461-0248.2002.00332.x

Kooijman A, Kooijman-Schouten M, Martinez-Hernandez G (2008) Alternative strategies to sustain $\mathrm{N}$-fertility in acid and calcaric beech forests: low microbial $\mathrm{N}$-demand versus high biological activity. Basic Appl Ecol 9:410-421, doi:10.1016/j.baae.2007.05.004

Levia D, Frost E (2003) A review and evaluation of stemflow literature in the hydrologic and biogeochemical cycles of forested and agricultural ecosystems. J Hydrol 274:1-29, doi:10.1016/S0022-1694(02)00399-2 
MacDonald JA, Dise NB, Matzner E, Armbruster M, Gundersen P, Forsius M (2002) Nitrogen input together with ecosystem nitrogen enrichment predict nitrate leaching from European forests. Global Change Biol 8:1028-1033, doi:10.1046/j.1365-2486.2002.00532.x

Michalzik B, Dorsch T, Matzner E (1997) Stability of dissolved organic nitrogen (DON) and mineral nitrogen in bulk precipitation and throughfall. Z Pflanzenernähr Bodenkd 160:433-434, doi:10.1002/jpln.19971600314

Millennium Ecosystem Assessment (2005) Ecosystems and human well-being: synthesis. Millennium Ecosystem Assessment series, Island Press, Washington D.C.

Molotch NP, Blanken PD, Link TE (2011) Snow: Hydrological and Ecological Feedbacks in Forests. In: Levia DF, CarlyleMoses D, Tanaka T (eds) Forest Hydrology and Biogeochemistry: Synthesis of Past Research and Future Directions, Ecological Studies, vol 216, Springer-Verlag, Berlin, Heidelberg, pp 541-555

Morin X, Fahse L, Scherer-Lorenzen M, Bugmann H (2011) Tree species richness promotes productivity in temperate forests through strong complementarity between species. Ecol Lett 14:1211-1219, doi:10.1111/j.14610248.2011.01691.x

Muller RN, Bormann FH (1976) Role of Erythronium americanum Ker. in energy flow and nutrient dynamics of a northern hardwood forest ecosystem. Science 193:11261128, doi:10.1126/science.193.4258.1126

Nadelhoffer KJ, Downs MR, Fry B, Aber JD, Magill AH, Melillo JM (1995) The fate of ${ }^{15} \mathrm{~N}$-labelled nitrate additions to a northern hardwood forest in eastern Maine, USA. Oecologia 103:292-301, doi:10.1007/BF00328617

Nadelhoffer KJ, Downs MR, Fry B (1999) Sinks for ${ }^{15} \mathrm{~N}$-enriched addtions to an oak forest and a red pine plantation. Ecol Appl 9:72-86, doi:10.1890/10510761(1999)009[0072:SFNEAT]2.0.CO;2

Olsson M, Falkengren-Grerup U (2003) Partitioning of nitrate uptake between trees and understory in oak forests. For Ecol Manage 179:311-320, doi:10.1016/S03781127(02)00544-3

Paquette A, Messier C (2011) The effect of biodiversity on tree productivity: from temperate to boreal forests. Glob Ecol Biogeogr 20:170-180, doi:10.1111/j.1466-8238.2010.00592.x

Park JH, Kalbitz K, Matzner E (2002) Resource control on the production of dissolved organic carbon and nitrogen in a deciduous forest floor. Soil Biol Biochem 34:813-822, doi:10.1016/S0038-0717(02)00011-1

Pollierer MM, Langel R, Körner C, Maraun M, Scheu S (2007) The underestimated importance of belowground carbon input for forest soil animal food webs. Ecol Lett 10:729736, doi:10.1111/j.1461-0248.2007.01064.x
Prietzel J, Bachmann S (2012) Changes in soil organic $\mathrm{C}$ and $\mathrm{N}$ stocks after forest transformation from Norway spruce and Scots pine into Douglas fir, Douglas fir/spruce, or European beech stands at different sites in southern Germany. For Ecol Manage 269:134-148, doi:10.1016/j.foreco.2011.12.034

Rosenkranz S, Wilcke W, Eisenhauer N, Oelmann Y (2012) Net ammonification as influenced by plant diversity in experimental grasslands. Soil Biol Biochem 48:78-87, doi:10.1016/j.soilbio.2012.01.008

Schall P, Ammer C (2013) How to quantify forest management intensity in Central European forests. Eur J Forest Res 102:379-396, doi:10.1007/s10342-013-0681-6

Scheu S (1987) The influence of earthworms (Lumbricidae) on the nitrogen dynamics in the soil litter system of a deciduous forest. Oecologia 72:197-201, doi:10.1007/BF00379267

Scheu S (1997) Effects of litter (beech and stinging nettle) and earthworms (Octolasion lacteum) on carbon and nutrient cycling in beech forests on a basalt-limestone gradient: a laboratory experiment. Biol Fertil Soils 24:384-393, doi:10.1007/s003740050262

Schulze IM, Bolte A, Schmidt W, Eichhorn J, Brumme R, Khanna P (2009) Phytomass, litter and net primary production of herbaceous layer. In: Brumme R, Khanna P (eds) Functioning and Management of European Beech Ecosystems, Ecological Studies, vol 208, Springer-Verlag, Berlin, Heidelberg, pp 155-181

Schwarz MT, Bischoff S, Blaser S, Boch S, Schmitt B, Thieme L, Fischer M, Michalzik B, Schulze ED, Siemens J, Wilcke W (2014) More efficient aboveground nitrogen use in more diverse Central European forest canopies. For Ecol Manage 313:274-282, doi:10.1016/j.foreco.2013.11.021

Solinger S, Kalbitz K, Matzner E (2001) Controls on the dynamics of dissolved organic carbon and nitrogen in a Central European deciduous forest. Biogeochemistry 55:327349, doi:10.1023/A:1011848326013

Tilman D, Wedin D, Knops J (1996) Productivity and sustainability influenced by biodiversity in grassland ecosystems. Nature 379:718-720, doi:10.1038/379718a0

Tørseth K, Aas W, Breivik K, Fjæraa AM, Fiebig M, Hjellbrekke AG, Myhre CL, Solberg S, Yttri KE (2012) Introduction to the European Monitoring and Evaluation Programme (EMEP) and observed atmospheric composition change during 1972-2009. Atm Chem Phys 12:5447-5481, doi:10.5194/acp-12-5447-2012

Verhoef HA, Brussaard L (1990) Decomposition and nitrogen mineralization in natural and agro-ecosystems: the contribution of soil animals. Biogeochemistry 11:175-211, doi:10.1007/BF00004496

Vesterdal L, Schmidt IK, Callesen I, Nilsson LO, Gundersen P (2008) Carbon and nitrogen in forest floor and mineral soil under six common European tree species. For Ecol Manage 255:35-48, doi:10.1016/j.foreco.2007.08.015 
Wardle DA, Bonner KI, Nicholson KS (1997) Biodiversity and plant litter: experimental evidence which does not support the view that enhanced species richness improves ecosystem function. Oikos 79:247-258, doi:10.2307/3546010

Xiong Y, Zeng H, Xia H, Guo D (2014) Interactions between leaf litter and soil organic matter on carbon and nitrogen mineralization in six forest litter-soil systems. Plant Soil 379:217-229, doi:10.1007/s11104-014-2033-9

Zak DR, Holmes WE, Burton AJ, Pregitzer KS, Talhelm AF (2008) Simulated atmospheric $\mathrm{NO}_{3}{ }^{-}$deposition increases soil organic matter by slowing decomposition. Ecol Appl 18:2016-2027, doi:10.1890/07-1743.1 